\title{
Reading Erich Fromm's The Art of Loving, or Why Loving Means Giving Nothing
}

Jeremy De Chavez

\begin{abstract}
The concept of love has been receiving sustained critical attention in recent critical discourse. While there was once reluctance to consider love an object of serious scholarly inquiry, contemporary philosophers and theorists have turned to love in theorizing issues of overlapping philosophical, ethical, cultural, and political concern. This paper seeks to contribute to the expanding discourse on love by offering a rereading of the work of critical theorist Erich Fromm. I reevaluate Fromm's work within the constellation of late capitalism, and I explore the utility of his prescriptions regarding amorous relations. How might his "art of loving" be realized given the problem of sexual difference and the commodification of love? Towards this goal, I place Fromm in conversation with Jacques Lacan to offer a way to rethink what it might mean to give one's lack to the other, a gesture of acceptance of one's symbolic castration.
\end{abstract}

Keywords: Fromm, Lacan, psychoanalysis, love

\section{Introduction}

ontemporary critical discourse has recently been intensely invested in
the concept of love. While there was once a reluctance to even
consider it as a proper object of scholarly inquiry, it is now becoming
a key concept in theorizing issues of overlapping philosophical, ethical,
cultural, and political concern. Several important contemporary philosophers
and theorists have granted love a renewed dignity as a philosophical concept
by turning to it to conceptualize the possibility of establishing genuine, non-
dominating, and non-totalizing relations with the other within the
constellation of the present historical situation. Alain Badiou has identified
love as an "Event" that constructs a "scene of Two," a situation that creates

(C) 2015 Jeremy C. De Chavez

http://www.kritike.org/journal/issue 17/de chavez december2015.pdf

ISSN 1908-7330 
the paradox of "identical difference." 1 For Jean-Luc Nancy love is an occurrence that "fractures" and "shatters" the subject, leaving him exposed and open to the Other, "an extreme movement, beyond the self, of a being reaching completion." 2 Conscripting the concept within a broader Feminist framework, Anna Jonasdottir posits that amorous relations offer "'worldcreating capacities' which contain the possibility of genuine reciprocity between co-equal subjects." 3 Further, there have also been attempts to theorize love as a conceptual adhesive to consolidate the oppressed so that they may forge collective resistance. For example, in Methodology of the Oppressed, Chela Sandoval conceives of love as a methodology to enact "oppositional social action." ${ }^{4}$ In Commonwealth, by Michael Hardt and Antonio Negri, love is the initiative of singularities to connect and form new assemblages to establish common interest, which is achieved through "the collective organization of our desires, a process of sentimental and political education." 5

This paper seeks to contribute to the expanding discourse on love by returning to the work of Erich Fromm, a critical theorist who emphasized the transformative and enabling possibilities of love at a time when it was considered thoroughly at the service of the period's dominant capitalist morality. Even his colleagues in the Frankfurt School thought his work was simply "the laboring[s] of the obvious, of everyday wisdom" 6 and is "sentimental and wrong."7 I offer a rereading of Fromm's The Art of Loving that places it in conversation with Jacques Lacan's theories on love and desire, and I posit that such a positioning is productive for it makes legible the contemporary relevance of Fromm's work that seems to be incompatible with the prevailing ethics of the current historical situation. Thus, I conscript Lacanian theories not with the intention of supplementing Fromm's putatively naïve prescriptions with theoretical sophistication, but rather, to make perceptible the structure of Fromm's thought without being

\footnotetext{
25.

${ }^{1}$ Alain Badiou, In Praise of Love, trans. by Peter Bush (New York: The New Press, 2012),

2 Nancy, Jean-Luc, The Inoperative Community (MN: University of Minnesota Press, 1991), 86 .

${ }^{3}$ Anna Jonasdottir, "Love Studies: A (Re)New(ed) Field of Knowledge Interests," in Love: A Question for Feminism in the 21 ${ }^{\text {st }}$ Century, ed. by Anna Jonassdottir and Ann Fergusson (London and New York: Routledge, 2014), 14.

${ }^{4}$ Chela Sandoval, Methodology of the Oppressed (Minnesota: University of Minnesota Press, 2000), 146.

5 Michael Hardt and Antonio Negri, Commonwealth (Massachusetts: Harvard University Press, 2009), 195.

${ }^{6}$ Herbert Marcuse, Eros and Civilization: A Philosophical Inquiry into Freud (Boston: Beacon Press, 1966), 250.

${ }^{7}$ Martin Jay, The Dialectical Imagination: A History of the Frankfurt School and the Institute of Social Research, 1923-1950 (Boston: Little Brown, 1973), 105.

(c) 2015 Jeremy C. De Chavez http://www.kritike.org/journal/issue 17/de chavez december2015.pdf ISSN 1908-7330
}

$((c))$ BY-NC-ND 
prematurely swayed by the bias of our dominant ethics. Biases bracketed, I argue that Fromm's work reveals an enabling dimension to certain concepts he develops in his most sustained meditation on love, The Art of Loving.

I turn to Psychoanalytic theory as a primary critical resource of my inquiry because I find that it has developed a substantial corpus of concepts that enables one to discern love's formal structure. Incidentally, this is also the reason why Alain Badiou insists that Psychoanalysis is indispensable in thinking about sexual differentiation. I proceed with the conviction that Psychoanalysis can tell us a lot about love even if generally it has had a rather ambivalent relationship towards it. Responding to the question "What can Psychoanalysis tell us about love?" Jacques-Alain Miller says:

A great deal, because it's an experience whose mainspring is love. It's a question of that automatic and more often than not unconscious love that the analysand brings to the analyst, and which is called transference. It's a contrived love, but made of the same stuff as true love. It sheds light on its mechanism: love is addressed to the one you think knows your true truth. But love allows you to think this truth will be likeable, agreeable, when in fact it's rather hard to bear. ${ }^{8}$

There is, of course, the problem of transitioning from intra- to intersubjective dynamics. It is rather a big leap to suggest that what an analyst discovers in very specific clinical situations could be a generic condition that is true for all. Advocates of psychoanalytic social theory have rarely attempted to define the conditions that make such a method valid or invalid (Why is it seemingly more justifiable to universalize the "logic of desire" or fantasy but questionable to do so for, say, hysteria or even for the Oedipus complex?). Instead, they have depended on a deconstructive counteroffensive, that is, to call into question the simple binary of individual and collective. However, in (Lacanian) psychoanalysis, one cannot speak purely of an individual psyche. Even psychopathologies that are seemingly particular to an individual emerge from a larger, inter-subjective social field, what Lacan refers to as the big Other. The (symbolic) consistency of a subject (in the Lacanian sense) is a mere "effect," for his actions, speech, and fantasies are designated by the big Other, the Symbolic Order. Paradoxically, the real(ity) of our being is what is inaccessible to us, and we mistake the

8 Jacque-Allain Miller, “On Love: We Love the One Who Responds to Our Question: Who Am I?" in Lacan.com, <http://www.lacan.com/symptom/?page_id=263>, 19 July 2015.

(c) 2015 Jeremy C. De Chavez http://www.kritike.org/journal/issue 17/de chavez december2015.pdf ISSN 1908-7330 
symbolic texture of our being with what is "in us more than ourselves." ${ }^{9}$ And, as Žižek and Salecl argue, it is that "kernel of the real" that is the true aim of love, "what is in the object more than the object itself." 10 If it is this inaccessible thing (das Ding), "the-beyond-of-the-signified," that love aims at, then it is surely outside the field of the perceptible.

\section{Prolegomenon: An Eventful Encounter with Erich Fromm}

Although I had heard of Erich Fromm long before I became interested in his ideas, ${ }^{11}$ what I consider to be our first meaningful encounter took place in a used bookstore in Toronto in 2008. While perusing the Psychology section of the bookstore, a pristine-looking paperback edition of Fromm's The Art of Loving caught my eye. When I opened the book, what first arrested my attention were not the words of Fromm, but someone else's. Written on the cover page, the pleasantly slanting cursive in blue ink read: "To my dearest " followed by a short dedication, then concluded with a rather trite "I love you," then signed. Though I am now unable to reproduce faithfully the contents of that message, I do remember thinking at the time that what I had in my hands was a special copy of The Art of Loving. It is not one that was owned by some profligate and/or impoverished student who immediately sold it off for a few dollars at the end of term, but rather one that was once a gift from a lover to his beloved.

That realization was accompanied by a spontaneous feeling of guilt for intruding into another's amorous universe. I happened to stumble upon information that could be devastatingly humiliating for the lover who penned those words: an object that he elevated as a privileged signifier of love had found its way into some used bookstore - what once was priceless, now sadly available at a bargain price. So, intrigued as I was by this book, I decided to buy a different copy, one that does a better job in keeping quiet about its history. That "special book," however, did make me want to ask questions: assuming that the beloved received that gift, why did it end up in a used bookstore? Desiring the most scandalous explanation, I concluded that their relationship ended badly, and that the beloved just wanted to remove all those objects that might bring back painful memories of her lover. Standard narratives of love make it seem that there are only two things that could be done to such amorous relics: they are either kept (as painful

9 Slavoj Žižek, Looking Awry: An Introduction to Lacan through Popular Culture (Massachusetts: MIT Press, 1998).

${ }^{10}$ Slavoj Žižek and Renata Salecl, eds., Gaze and Voice as Love Objects (Durham and London: Duke UP, 1996), 3.

${ }^{11} \mathrm{~A}$ friend who wrote his Master's research project on Erich Fromm incessantly talked about him when we were doing graduate studies at the National University of Singapore.

(c) 2015 Jeremy C. De Chavez

http://www.kritike.org/journal/issue 17/de chavez december2015.pdf

ISSN 1908-7330

(cc) BY-NC-ND 
reminders of what once was) or destroyed (in a ritualistic gesture of closure). But rarely are they sold.

I begin this paper with this anecdote not only because it dramatizes so clearly certain aspects of the fundamental structure of love and how those very aspects have been contaminated by the logic of capital. Psychoanalysis suggests that the concept of "the gift" is a crucial component of the amorous structure. Freud traces the practice of gift giving to infantile anal eroticism. In "On Transformations of Instinct as Exemplified in Anal Erotism," he writes: "[The] first meaning which a child's interest in faeces develops is that of a gift ... Since his faeces are his first gift, the child easily transfers his interest from that substance to the new one which he comes across as the most valuable gift in life."12 The child, yet to be alienated from his labor, considers his faeces not as a worthless piece of shit but as a product of a work of love. It is for him a part of his body that he has to give up (to the (m)other who suffers from lack). Thus, it is the first time that he realizes the split meaning of defecation: as a narcissistic activity (when he experiences pleasure from defecation) and as a sacrifice (object love). When adults reenact (as transferential love) gift giving as this practice of generosity, are they not really just exchanging pieces of shit? That is, they are simply giving to each other objects that have been subtracted of (use-)value, of vitamins, and nutrients? It is no surprise then that the less use-value a gift has, the more likely it is able to signify love. Toilet plungers, screwdriver sets, and dustpans, useful as they are, tend to fall short in making a loved one feel special. Is this not exactly what $O$. Henry's famous short story "The Gift of the Magi" (1906) renders perfectly clear? ${ }^{13}$

Jacques Lacan, in his famous essay "The Meaning of the Phallus" (1985), suggests that giving is not merely a component of the practice of love but the act of loving itself. ${ }^{14}$ The lover is one who gives to the (sexed) other. But

\footnotetext{
12 Sigmund Freud, The Standard Edition of the Complete Psychological Works of Sigmund Freud, Volume I (1886-1899) (London: Hogarth Press, 1966), 130-131.

${ }^{13} \mathrm{O}$. Henry's story is about a poor young couple, James and Della, and their secret desire to buy each other Christmas gifts that would approximate the intensity of their amorous feelings. To circumvent financial constraints, they both sell, without the other knowing, something of value that they possess: for James his heirloom pocket watch and for Della her long, beautiful hair. The twist is that James uses the money to buy Della a set of jewel-encrusted combs and Della to buy James a platinum chain for his watch. Their personal sacrifice thus renders the other's gift useless. Standard readings of the story suggest that it is ultimately their sacrifice that signifies love rather than the actual gifts themselves. However, one could imagine an alternative ending where the couple finds a way to raise the funds through other means and the gifts retain their use-value. Even if a sacrifice is still involved-James puts in the extra overtime hours or Della risks humiliation by borrowing money from her estranged parents, for example-the attempt of the story to be a scene of presentation for love is indubitably weaker.

${ }^{14}$ Jacque Lacan, Feminine Sexuality, ed. by Juliet Mitchell and Jacqueline Rose, trans. by Jacqueline Rose (London and New York: Norton, 1985). Emphasis mine.
}

(c) 2015 Jeremy C. De Chavez

http://www.kritike.org/journal/issue 17/de chavez december2015.pdf

ISSN 1908-7330 
what does he give? "[The] gift of something which it does not have."15 Needless to say, Lacan does not mean that lovers are those who give false promises or stolen goods; rather, he means that what lovers give to each other is lack itself, the phallus. This is a complicated formulation that I will engage in in this paper. For now, however, it will be sufficient to say that the "phallus" does not stand for pleasure, but rather its endless deferral. For Lacan, lovers do not provide each other with fulfillment, but rather false hopes, a romance of (dis)illusion(ment).

Erich Fromm also equates love with giving. His famous book The Art of Loving (2000), which according to the back cover has helped "hundreds of thousands of men and women achieve productive lives by developing their hidden capacities for love,"16 proposes a methodology of loving based on "active penetration," which for Fromm is primarily a form of giving, "the highest expression of potency." 17 Suffice it to say, for the contemporary reader, Fromm's word choice is somewhat alarming because it appears to be undergirded by heterosexist and heteronormative assumptions. And indeed, he has received numerous criticisms on that score-among them those coming from no less than his colleagues at the Frankfurt School. But is this a valid enough reason to leave Fromm in the dustbin of academic history? I suggest that there is more to Fromm than meets the eye, for his notion of giving as "active penetration" allows us to think of this amorous act outside the coordinates of capital and perversion. The political utility of psychoanalysis is in large part linked to its extensive theorizations of forms of perversion. Fromm's work offers a new way for psychoanalysis to participate in thinking the ethico-political by expanding the notion of "giving" within the context of the sexed relation.

I take my chance encounter with Erich Fromm (in a used bookstore no less!) as an opportunity to return to his ideas and reconsider them in light of the contemporary forms of attachment we generously label as love. Fromm's The Art of Loving had the audacity to instruct individuals on how to become masters of the amorous arts, an audacity that made it difficult for Herbert Marcuse and Theodor W. Adorno, for example, to take him seriously. Further, his thought seems to be weighed down by unacceptable heteronormative assumptions that are arguably no longer compatible with our contemporary values. Thus, I propose to read The Art of Loving through a Lacanian lens to offer an alternative reading of Fromm's theories on love that might resonate more strongly with contemporary subjectivities.

\footnotetext{
${ }^{15}$ Ibid., 80. Emphasis mine.

${ }^{16}$ Erich Fromm, The Art of Loving (New York: HarperCollins, 2000), back cover.

${ }^{17}$ Ibid., 21.
}

(c) 2015 Jeremy C. De Chavez http://www.kritike.org/journal/issue 17/de chavez december2015.pdf ISSN 1908-7330

(c) BY-NC-ND 


\section{The (Un)Critical Theory of Erich Fromm}

Once upon a time, Erich Fromm was an academic superstar. His work was able to speak to a broader audience compared to most psychoanalytic theorists. Adam Phillips observes that as a writer he "is calm and intelligible...wary of mystification."18 Fromm wrote a number of bestsellers, among them Fear of Freedom (1941), The Sane Society (1955), The Heart of Man (1964), The Revolution of Hope (1968), To Have or To Be? (1976), and of course The Art of Loving (1956). However, his popularity was confined to his own lifetime, and now, his work has been relegated to the dustbin of intellectual history. To be sure, there were a few attempts to rectify this neglect, yet no "return to Fromm" has sparked the kind of academic wildfire that occurred for, say, Emmanuel Levinas or for Herbert Marcuse. ${ }^{19}$ His disappearance from academic consideration is, at least in part, a consequence of his highly readable prose. In today's intellectual climate, immortality appears to be linked to inaccessibility. Phillips notes that this is perhaps the reason why "it was the more hermetic members of the Frankfurt School, Theodor Adorno and Walter Benjamin in particular, who had more staying power than Fromm." 20

Further, Fromm has achieved the perhaps regrettable reputation of being a "common-sense" theorist. He is a popularizer of "philosophy" rather than a visionary. Nothing makes an idea more unpopular with intellectuals than its being rubber stamped as commonsense. Robert Bocock in his Freud and Modern Society (1978) - a study that explores the impact of psychoanalysis in the development of Sociology-portrays Fromm's revisions of Freudian theory as regressive rather than productive. He writes: "[Fromm] seems to be a return to pre-Freudian thought rather than a building upon Freud." For Bocock, Fromm perverts Freud's teachings so that they may be more palatable to a mass audience, revising Freud to achieve compatibility with the dominant morality. He consequently dismisses Fromm's work as nothing more than "a form of inspirational literature rather than a rigorous sociological or philosophical analysis." 21

Bocock's uncharitable pronouncement is not just a contemporary reassessment, but one that has been leveled against Fromm even during the height of his scholarly productivity. It should be noted that Fromm's

18 Adam Phillips, On Flirtation: Psychoanalytic Essays on the Uncommitted Life (Cambridge: Harvard University Press, 1994), 136.

19 McLaughlin has suggested that recent scholarly works on Fromm-such as Friedman (2014), Durkin (2014), Braune (2014) - are making up for decades of apparent academic neglect.

${ }^{20}$ Ibid., 133-134.

${ }^{21}$ Robert Bocock, Freud and Modern Society: An Outline and Analysis of Freud's Sociology (New York: Holmes and Meier, 1978), 256.

(c) 2015 Jeremy C. De Chavez http://www.kritike.org/journal/issue 17/de chavez december2015.pdf ISSN 1908-7330 
colleagues at the Institute of Social Research were responsible in large part for his image as an impotent moral philosopher and a naïve utopian who could only offer "the power of positive thinking," to use Herbert Marcuse's words. ${ }^{22}$

It is well known that the original members of the Frankfurt School agonized over the fear of being co-opted and integrated into the dominant culture. So it is no surprise that Fromm's modifications of Freudian theory, which Marcuse alleges are "the laboring[s] of the obvious, of everyday wisdom," were regarded as threats to the group's intellectual integrity. ${ }^{23}$ Adorno, the first among the Institute members to openly criticize Fromm, accused him of grossly exaggerating the transformative powers of love. ${ }^{24}$ Fromm's article of 1935 in Zeitschrift fur Sozialforshchung entitled "The Social Determinateness of Psychoanalytic Therapy," which argued that the cold analyst cloaked authoritarian tendencies that should be rejected in favor of a more kind and caring analyst, was dismissed by Adorno as simply "sentimental and wrong." Adorno told Horkheimer that "silly arguments like 'lack of kindness' cannot be permitted ... I cannot keep from you the fact that I see [Fromm's] work as a real threat to the line of the journal." 25

Adorno's open hostility towards Fromm is commonplace in historical accounts of the Frankfurt School, and some accounts even portray their conflict as having exceeded professional bounds. ${ }^{26}$ In his book The Art of Living: Erich Fromm's Life and Works, Gerhard Knapp writes:

Theodor W. Adorno ... disliked Fromm intensely. This feeling was reciprocal. Adorno had insulted Lowenthal and Fromm, who were both still orthodox in their adherence to Judaism at the time, by mockingly calling them "professional Jews" ... Fromm's serious, unblinking outlook on life must have clashed with the

${ }^{22}$ Marcuse, Eros and Civilization, 262.
${ }^{23}$ Ibid., 250.
${ }_{24}$ Fromm responds by arguing that "genuine love, far from being merely 'ideological'...is actually quite rare in contemporary society because it is out of step with the prevailing character of social relations." See Daniel Burston, The Legacy of Erich Fromm (Massachusetts: Harvard UP, 1991), 216.

${ }^{25}$ In a letter to Horkheimer dated 21 March 1936. See Jay, The Dialectical Imagination, 105.

${ }^{26}$ Burston suggests that Adorno's alleged misguided critique of Fromm is due to an "elementary misunderstanding of the clinical issues" in Fromm's article, and concludes that Adorno's assessment "was somewhat obtuse politically, and tangential to the issues Fromm was addressing. See Burston, The Legacy of Erich Fromm, 213-214.

(c) 2015 Jeremy C. De Chavez http://www.kritike.org/journal/issue 17/de chavez december2015.pdf

ISSN 1908-7330

(c) $\mathrm{BY}-\mathrm{NC}-\mathrm{ND}$ 
whimsical and caustically self-ironic personalities of Adorno, Horkheimer, and Pollock. ${ }^{27}$

For Adorno, Fromm's "serious, unblinking outlook on life" translated into a kind of naïve uncritical theory. Fromm insisted on the possibility of love in a world that he himself describes as repressive. Adorno saw this as problematic. He writes: “... any direct evidence of love serves only at confirming the very same conditions which breed hatred." 28

If Adorno seems to be have been critical of Fromm from the start, most of the authoritative literature on the history of the Frankfurt School portrays Horkheimer's falling out with Fromm as a slower process. Horkheimer was especially enthusiastic about supplementing the Institute's brand of neo-Marxism with psychoanalytic theory. Historical accounts have suggested that Horkheimer worked overtime in trying to make the Institute an accommodating space for psychoanalytic thought. ${ }^{29}$ Fromm was initiated into the Frankfurt School mainly because of Horkheimer's efforts to have the Psychoanalytic Institute, of which Fromm was a member, granted the status of "guest institute" by the University of Frankfurt (and thus making it the first ever Freudian organization to be connected to a German university). ${ }^{30} \mathrm{In}$ Critical Theory, Politics and Society, Peter Stirk suggests that initially "Fromm's influence was central to the Institute's self-perception," and Horkheimer held him in high regard. This good working relationship, however, would turn sour by 1934. In a letter to Pollock, Horkheimer revealed the reasons for his change of heart. Fromm, according to Horkheimer, was "trying to stay on good terms with too many people" and was lacking a "maliciously sharp eye for prevalent conditions." ${ }^{31}$

\section{Rereading Fromm}

I propose to read Fromm's theory of love in conjunction with Jacques Lacan's theories on sexuation. Suffice it to say, my "return to Fromm" does not consist of merely trying to resurrect the analytical concepts he developed so that those could be blindly applied as a kind of general/universal corrective to current social ills, but rather it is to discover that which his dominant

\footnotetext{
${ }^{27}$ Gerhard Knapp, The Art of Living: Erich Fromm's Life and Works (NY and Frankfurt: Peter Lang, 1993), 35-36.

28 Jay, The Dialectical Imagination, 105.

${ }^{29}$ See the following: Jay, The Dialectical Imagination; Wiggershaus, The Frankfurt School; and Peter Stirk, Critical Theory, Politics, and Society: An Introduction (New York: Continuum, 2000).

${ }^{30}$ The Frankfurt Psychoanalytic Institute was an organization formed by Horkheimer's analyst Karl Landauer.

${ }^{31}$ Rolf Wiggershaus, The Frankfurt School: Its History, Theories, and Political Significance, trans. by Michael Robertson (Massachusetts: Polity Press, 1994), 266.
}

(c) 2015 Jeremy C. De Chavez http://www.kritike.org/journal/issue 17/de chavez december2015.pdf ISSN 1908-7330 


\section{WHY LOVING MEANS GIVING NOTHING}

academic reception was unable to discern. I claim that when one "looks awry" (to use the words of Slavoj Žižek) at the work of Fromm, one discovers a surprising compatibility with Lacanian motifs. At first blush, Lacan and Fromm make for strange bedfellows, for even more than the American ego psychologists, Fromm's ideas appear to be anathema to Lacan's. Fromm's humanism, his belief in the existence of a universal, transhistorical human nature, his emphasis on social psychology, his rejection of the death drive, do not seem to sit well with standard interpretations of Lacanian thought. It is, however, precisely this apparent incompatibility that makes possible new and fruitful ways of reading that often escape formulaic modes of processing information. Slavoj Žižek uses the term "short-circuiting" to describe the resulting effect of reading seemingly incompatible texts together (at least, incompatible in terms of their positive content), to "cross wires that do not usually touch." 32

I endeavor to "short circuit" Fromm using Lacan not to come up with new concepts but rather to see the old ones that he already formulated in new ways (and in doing so hopefully liberate their hidden radical potential). The difference between formulating new concepts and "looking awry" at old ones is perhaps small but nevertheless crucial. ${ }^{33}$ With the former, we begin in the subjunctive mode: If Fromm and/or Lacan were alive today, what would they likely say about the current historical condition? This is of course followed by the rather ambitious attempt to think in the same manner as a great theorist, supported by the rather questionable premise that the trajectory of that theorist's thought unfolds following a predictable pattern that we are now in the fortunate position to take to its inevitable conclusion. However, with the latter, we assume that a theorist's prescriptions, even if conceived within the specificities of different historical conditions, nevertheless, can surprisingly shed light on current problems.

\section{The Art of Hysterical Loving}

So, according to Fromm, how does one become a master in the art of loving?

For a psychoanalytic theorist known for being "calm and intelligible" and for refusing to "promote those forms of mandarin intelligence that could produce convincing critiques of culture that hardly anyone in the culture was able to read," 34 it is surprisingly difficult to tell how Fromm satisfies the burden his book The Art of Loving sets up. He offers love as the "answer to the

\footnotetext{
${ }^{2}$ Slavoj Žižek, The Parallax View (Massachusetts: MIT Press, 2006), ix.

33 Slavoj Žižek, Looking Awry: An Introduction to Lacan through Popular Culture (Massachusetts: MIT Press, 1998), 1.

${ }^{34}$ Phillips, On Flirtation: Psychoanalytic Essays on the Uncommitted Life, 136, 133.

(c) 2015 Jeremy C. De Chavez http://www.kritike.org/journal/issue 17/de chavez december2015.pdf ISSN 1908-7330
}

(c) BY-NC-ND 
problem of human existence," which is the "question of how to overcome separateness." 35 He bewails the tendency of most people to overcome this separateness through conformity, which includes "orgiastic unions." 36 And then he discusses different "types" of love-parental, brotherly, motherly, erotic, self-love, love of God-and shows how each attempts to resolve the fundamental anxiety brought about by the condition of separateness. ${ }^{37}$

He speaks of love and of the art of loving as the only legitimate means to overcome human separateness. Love is a sincere way of establishing relations with the other and a basis on which a meaningful and ethical life could be lived. Love could also sever our dependence on those things that our capitalist orientation desires: "success, prestige, money, power." ${ }^{38}$ Being a master of the art of loving has to be a matter of ultimate concern, therefore. Fromm thus provides his readers with the reason for love and for the necessity of love. But what about the practice of love?

In the section of the book called "The Practice of Love," Fromm identifies several traits that every lover worth the name should have: discipline, concentration, and patience. He then gives rather concrete suggestions on how these traits could be developed. Most of his suggestions are suspiciously prosaic and old-fashioned. His prescription for developing discipline:

Our grandfathers would have been much better
equipped to answer this question. Their
recommendation was to get up early in the morning, not
to indulge in necessary luxuries, to work hard...To get
up at a regular hour, to devote a regular amount of time
during the day for activities such as meditating, reading,
listening to music, walking; not to indulge, at least not
beyond a certain minimum, in escapist activities like
mystery stories and movies, not to overeat and
overdrink are some obvious rudimentary rules. ${ }^{39}$

After these rather overbearingly moralistic prescriptions, however, Fromm anticipates his reader's disappointment. His suggestions are

\footnotetext{
${ }^{35}$ Fromm, The Art of Loving, 9.

${ }^{36}$ Ibid., 12.

${ }^{37}$ For Fromm, separateness is the consequence of being an animal with reason, "life being aware of itself." This awareness makes him anxious of his "short life span, of the fact that without his will he is born and against his will he dies, that he will die before those whom he loves, or they before him, of his helplessness before the forces of nature and of society, all this makes his separate, disunited existence an unbearable prison," ibid., 8.

38 Ibid., 5.

${ }^{39}$ Ibid., 103.
}

(C) 2015 Jeremy C. De Chavez

http://www.kritike.org/journal/issue 17/de chavez december2015.pdf

ISSN 1908-7330 
accompanied by a caveat: "... many readers of this book expect to be given prescriptions of 'how to do it yourself,' and that means in our case to be taught how to love. I am afraid that anyone who approaches this last chapter in this spirit will be gravely disappointed." 40 As with any art that demands an original and creative mind and spirit, the art of loving "can be practiced only by oneself." 41

In the opening chapter of the book, Fromm makes the mastery of the art of loving seem like a simple process. It can be "divided conveniently into two parts," he writes, "one, the mastery of the theory; the other, the mastery of practice." 42 But what the careful reader of Fromm discovers by the time he or she reaches the conclusion of the book is that Fromm only frustrates their desire for knowledge about love and consequently says nothing about how love may be fruitfully practiced. This does not mean, however, that The Art of Loving fails in providing its reader with new knowledge about love, but that it does so by positioning its reader in a hysterical position of interpretation, a position of uncertainty about the (desire of the) other.

Contrast the hysterical position with what we might call the perverse position of interpretation. Like the pervert who is sure of the desire of the Other and thus effectively puts into action what the hysteric only keeps as fantasy, the perverse reader installs the text fully within the coordinates of his or her fantasy, which supports and gives Imaginary body to his or her interpretation. For example, the perverse reader of the Christian commandment "Thou shall not kill" knows first and foremost that the directive is addressed to him or her, and that it applies to only a certain group of people (but perhaps not to heathens, non-believers, animals, criminals). The hysteric reader, however, asks "What does the other mean when he says Thou shall not kill?" "And why does he say it to me?" "Is the directive even addressed to me?" As Žižek notes, the hysteric understands the demand of the Master as "I'm demanding this of you, but what I'm really demanding of you is to refute my demand because this is not it." ${ }^{43}$ Thus, hysteria could be read as a "radically ambiguous protest against the Master's interpellation." 44

The psychoanalytic wager is that love is fundamentally a problem of knowledge. Love is a matter of "knowing," of properly positioning oneself in relation to the Other's desire: "How may I be able to situate myself within the Other's desire?" Of course, this question is posed not entirely for the benefit of the other; needless to say, it cloaks a self-serving agenda. It is only within

\footnotetext{
${ }^{40}$ Ibid., 99.

${ }^{41}$ Ibid., 99.

42 Ibid., 5.

43 Slavoj Žižek, The Sublime Object of Ideology (London and NY: Verso, 1989), 112.

${ }^{44}$ Slavoj Žižek, The Indivisible Remainder: On Schelling and Related Matters (London and
} NY: Verso, 1996), 163.

(c) 2015 Jeremy C. De Chavez http://www.kritike.org/journal/issue 17/de chavez december2015.pdf ISSN 1908-7330

(cc) BY-NC-ND 
the coordinates of the Other's desire that the Other is in the position to tell me the truth about myself. The desire to love then is fueled by the belief that by loving another, you will get to a truth about yourself. Needless to say, the loved object does not possess the truth about you, and, sans the veil of idealization, the elevated object of love is really just another individual in his or her plain, fragile, imbecilic being. ${ }^{45}$

Yet, this path towards amorous knowledge cannot be properly attained via the perverse route. The pervert disavows castration and in mistakenly believing that he has the phallus, locks himself in the closed loop of desire under the illusion that he undermines "the very foundations of symbolic authority," not realizing his (false) subversion "fits the existing power constellation perfectly." 46 It is via the hysterical route that knowledge about love may be produced. It is hysterical uncertainty that makes the subject question the master's injunctions. "You tell me that this is how to love, but is it really?"

Lacan's definition of love as giving the "gift of something which [one] does not have" 47 could thus be understood within the opposition of perversion and hysteria. The pervert who thinks he has the phallus gives the beloved those objects that signify the full value of his love, an object brimming with the fullness of meaning. In contrast, what the uncertain amorous hysteric gives to the other is lack itself.

\section{Have Nothing to Give, and Here It Is}

Fromm's The Art of Loving attempts to think how love aims to suture sexual difference; however, rather than challenging the ruling hegemony via perverse strategies that obscure the reality of sexual difference, Fromm works with the Lacanian premise of a fundamental sexual division, and argues that "love," as he defines it, is a way to transcend this fundamental gap through

${ }^{45}$ Herein lies the explanation for the curious dynamic between the analyst and analysand in a Lacanian clinic, the scene where the transferential drama is played out. The analysand brings his or her problems to the clinic, hoping that the analyst can alleviate his or her psychological distress by revealing the truth of his or her disorder. The ethical analyst, of course, does not simply "diagnose" the problem. Easy - and perhaps even (sadistically) pleasurable-as it is to reproach the analysand directly for being too selfish, too narcissistic, too fixated on his or her mother, etcetera, the analyst takes a more unconventional path: he "frustrates" the analysand by purposely foiling his or her "demands," by leaving his or her questions strategically (and often painfully) unanswered. The logic behind this curious practice is that the analysand has to realize in his or her own terms how he or she is caught in the closed loop of desire. Lacan writes: "To have carried an analysis through to its end is no more nor less than to have encountered that limit in which the problematic of desire is raised" (Seminar VII 300).

${ }^{46}$ Slavoj Žižek, The Ticklish Subject: The Absent Center of Political Ontology (London and NY: Verso, 1999), 250-251.

${ }^{47}$ Lacan, Feminine Sexuality, 80.

(c) 2015 Jeremy C. De Chavez

http://www.kritike.org/journal/issue 17/de chavez december2015.pdf

ISSN 1908-7330

(cc) BY-NC-ND 
what Fromm calls "penetration." Again, it is easy to accuse Fromm of simply accepting the phallogocentric vocabulary of psychoanalysis by using the term "penetration" and suggesting that it is an active form of loving. However, reading Fromm's notion of "penetration" together with Lacan's distinction of the two sexualized positions as fundamentally the difference between "being" and "having" the phallus unveils a structure of thought that allows for new ways of thinking about sexual relations.

In The Art of Loving, Fromm posits that love and knowledge are related insofar as there is a "basic need" to discover the "secret of man," the unfathomable secret of the other. ${ }^{48}$ For him, the attempt to overcome the sexual division is primarily a will-to-knowledge. Yet, according to Fromm, it is accompanied by a fundamental paradox: the more we attempt to grasp the other in the (totalizing) grip of knowledge the more his secret "nucleus" eludes us. Fromm posits that there are two ways to overcome this paradox. The first is through the domination of the other: "It is that of complete power over another person ... to torture him, to force him to betray his secret in his suffering." For Fromm this is where the "essential motivation for the depth and intensity of cruelty and destructiveness" comes from. ${ }^{49}$ The second is through love. Suffice it to say, for Fromm, the amorous relation is not a power relation, so any attempt to produce knowledge about the loved object is accomplished through methods other than "force." What is this method then? Put simply: it is love.

Fromm's suggestion that love is the key that unlocks the other's secret should not be read as a naïve and unworkable prescription to suture the sexual division. What Fromm is suggesting here is supported by axioms central to psychoanalytic theory itself. Fromm writes:

The other path to knowing "the secret" is love. Love is active penetration of the other person, in which my desire to know is stilled by union. In the act of fusion I know you, I know myself, I know everybody-and I "know" nothing ... In the act of loving, of giving myself, in the act of penetrating the other person, I find myself, I discover myself, I discover us both, I discover man ... [Love] transcends thought, it transcends words. ${ }^{50}$

Let us spend some time unpacking this rich passage. Let us start from the obvious blatant paradox in the passage: the idea that love leads to knowledge, yet it is the knowledge that "I know nothing." Surely, Fromm is

${ }^{48}$ Fromm, The Art of Loving, 27.

49 Ibid., 28.

${ }^{50}$ Ibid., 28-29. Emphasis mine.

(C) 2015 Jeremy C. De Chavez

http://www.kritike.org/journal/issue 17/de chavez december2015.pdf

ISSN 1908-7330

(c) BY-NC-ND 
not merely suggesting that love leads an individual to assume a posture of humility: the trite (Westernized) Taoist idea that emptiness not fullness is what brings about inner tranquility. The key that unlocks the "secret" of the passage is the word that sticks out, phallus-like, in the text. What does Fromm mean by "active penetration"? And why does he equate "active penetration" with love?

First of all, it should be said that Fromm does not use the Freudian definition of the "active-passive" dichotomy as an instinctual aim that later becomes superimposed onto sexual difference. Fromm equates "activity" with "giving." He writes: "Love is an activity, not a passive affect ... In the most general way, the active character of love can be described by stating that love is primarily giving not receiving." 51

If in Fromm's vocabulary, "activity" is equated to giving, what does giving entail? Throughout The Art of Loving, Fromm remains vague about what he means by the term. Ironically, he does not give his reader a sufficient enough definition of what it means to "give." The most he could provide is a seemingly empty definition, a rather lengthy list that seems to say less as it grows longer52: "What does one person give to another? ... [He] gives him of that which is alive in him; he gives him of his joy, of his interest, of his understanding, of his knowledge, of his humor, of his sadness-of all expressions and manifestations of that which is alive in him." 53

Let us in the meantime dwell on the idea of "active penetration" as giving the other the phallic signifier. In doing so, we assume that it is the phallus that is "alive in him" - that which gives symbolic body to his joys, interest, understanding, knowledge, humor, sadness, and so on, and positions the subject within the Symbolic Order (Also, is not symbolic death the result of challenging the Law of the Father?). What does it mean to give the phallus, the signifier of lack, to the other? Obviously, one cannot give one's joy, or understanding, or humor to another; however, one can displace one's desire for joy, desire for understanding, and so on.

In the act of "giving" the phallus, what one really gives the other is one's lack. This is what Lacan means when he defines love as giving to the other what one does not have. Loving is thus a kind of act of symbolic castration, for to love means to accept that one is a being with lack. JacquesAlain Miller would go so far as to say that "Loving feminizes," for the lover must accept his or her (symbolic) castration. Thus, the act of loving could only really be properly accomplished from the feminine position. What does this mean?

\footnotetext{
51 Ibid., 21. Emphasis mine.

${ }^{52} \mathrm{I}$ am very much aware of the phallic imagery that haunts this paragraph.

${ }^{53}$ Fromm, The Art of Loving, 23.
}

(c) 2015 Jeremy C. De Chavez http://www.kritike.org/journal/issue 17/de chavez december2015.pdf ISSN 1908-7330 
Let us return to Lacan's fundamental distinction of the two positions. Lacan claims that there are two sexualized positions designated as "Man" and "Woman." These two positions are purely symbolic and have no biological, empirical, or social basis, but are so termed depending on the subject's relation to the phallic signifier (of wanting to have or to be the phallus). Those two positions constitute two wholly separate realms of experience, and no real connection between the two positions can be successfully established. This is because the laws of the Symbolic and the deceptive images of the Imaginary always mediate sexual relations; thus, subjects cannot transcend the perimeters defined by their respective fantasies (Hence, Lacan's famous pronouncement: "There is no sexual relation." ${ }^{54}$

In trying to say everything, Fromm ends up saying nothing. Rather than giving his readers "knowledge," he ends up giving them empty signifiers. What does it mean to give one's joy or one's interest? We just end up asking more (clarificatory) questions. Fromm displaces the lack in his own text onto his readers. He gives his reader phallic signifiers. The Art of Loving thus offers its readers "lack", that is, a gesture of love.

Department of Literature, De La Salle University-Manila, Philippines

\section{References}

Badiou, Alain, In Praise of Love, trans. by Peter Bush (New York: The New Press, 2012).

Bergman, Martin, The Anatomy of Love New York: Columbia University Press).

Bocock, Robert, Freud and Modern Society: An Outline and Analysis of Freud's Sociology (New York: Holmes and Meier, 1978).

Burston, Daniel, The Legacy of Erich Fromm (Massachusetts: Harvard University Press, 1991).

Freud, Sigmund, The Standard Edition of the Complete Psychological Works of Sigmund Freud, Volume 1 (1886-1899), trans. and ed. by James Strachey, Anna Freud, Alix Strachey, and Alan Tyson (London: Hogarth Press, 1966).

Fromm, Erich, Escape from Freedom (New York: Holt, Rinehart, and Winston, 1941).

The Art of Loving (New York: HarperCollins, 2000).

The Heart of Man (New York: Harper \& Row, 1964).

The Same Society (New York: Holt, Rinehart, and Winston,

1955).

${ }^{54}$ Lacan, Jacques, Seminar XX: On Feminine Sexuality, the Limits of Love and Knowledge, 1972-1973, trans. by Bruce Fink (London and NY: Norton, 1988), 6.

(c) 2015 Jeremy C. De Chavez

http://www.kritike.org/journal/issue 17/de chavez december2015.pdf

ISSN 1908-7330

(c) $)$ BY-NC-ND 
Hardt, Michael and Antonio Negri, Commonwealth (Massachusetts: Harvard University Press, 2009).

Jay, Martin, The Dialectical Imagination: A History of the Frankfurt School and the Institute of Social Researach, 1923-1950 (Boston: Little Brown, 1973).

Knapp, Gerhard, The Art of Living: Erich Fromm's Life and Works (New York and Frankfurt: Peter Lang, 1993).

Jonasdottir, Anna, "Love Studies: A (Re)New(ed) Field of Knowledge Interests," in Love: A Question for Feminism in the 21 ${ }^{\text {st }}$ Century, ed. by Anna Jonassdotir and Ann Fergusson (London and New York: Routledge, 2014).

Lacan, Jacques, Seminar XX: On Feminine Sexuality, the Limits of Love and Knowledge, 1972-1973, trans. by Bruce Fink (London and New York: Norton, 1988).

Feminine Sexuality, ed. by Juliet Mitchell and Jacqueline Rose, trans. by Jacqueline Rose (London and New York: Norton, 1985).

Marcuse, Herbert, Eros and Civilization: A Philosophical Inquiry into Freud (Boston: Beacon Press, 1966).

McLaughlin, Neil, “Erich Fromm's Critical Theory: Prophetic, Scholarly, or Revolutionary?" in Canadian Journal of Sociology, 40:1 (2015).

Miller, Jacques-Allain, "On Love: We Love the One Who Responds to Our Question: Who Am I?" in Lacan.com, < http://www.lacan.com/symptom/?page id=263>, 19 July 2015.

Nancy, Jean-Luc, The Inoperative Community (Minnesota: University of Minnesota Press, 1991).

Henry, O., "The Gift of the Magi," in Project Gutenberg, < http://www.gutenberg.org/files/7256/7256-h/7256-h.htm>, 19 July 2015.

Phillips, Adam, On Flirtation: Psychoanalytic Essays on the Uncommitted Life (Cambridge: Harvard University Press, 1994).

Sandoval, Chela, Methodology of the Oppressed (Minnesota: University of Minnesota Press, 2000).

Stirk, Peter, Critical Theory, Politics, and Society: An Introduction (New York: Continuum, 2000).

Wiggershaus, Rolf, The Frankfurt School: Its History, Theories, and Political Significance, trans. by Michael Robertson (Massachusetts: Polity Press, 1994).

Zizek, Slavoj, Looking Awry: An Introduction to Lacan through Popular Culture (Massachusetts: The MIT Press, 1998). The Indivisible Remainder: On Schelling and Related Matters (London and New York: Verso, 1996). The Parallax View (Massachusetts: The MIT Press, 2006).

(c) 2015 Jeremy C. De Chavez http://www.kritike.org/journal/issue 17/de chavez december2015.pdf ISSN 1908-7330 


\section{WHY LOVING MEANS GIVING NOTHING}

The Ticklish Subject: The Absent Center of Political Ontology (London and New York: Verso, 1999). , The Sublime Object of Ideology (London and New York: Verso, 1989).

Žižek, Slavoj and Renata Salecl, eds., Gaze and Voice as Love Objects (Durham and London: Duke University Press, 1996). 